Proceeding of the International Scientifical Conference May $23^{\text {th }}-24^{\text {th }}, 2014$

Volume III

\title{
TRANSFORMATION OF NEEDS OF THE DISABLED IN THE CONTEXT OF MUSIC THERAPY
}

\author{
Lithuanian University of Educational Sciences
}

\begin{abstract}
The article presents the case study, which highlights the limitation of physical, social and self-expression needs, caused by disability. It is concluded that the needs of the disabled transformed during music activity and changed their hierarchy - the social needs and self-expression have become more important than physical. The disabled has established himself as an older and more experienced person's identity, giving the advice and assessments on musical themes; a partner's and a friend's identity - he has not complained about his pains, and has learned to notice the other people's emotions; the physical opportunities have extended as well - the disabled started exercising and began to show more willingness to move in the wheelchair. This substantiates the studies of Stige (2004), Moreno (2006), predicating that if the person's life is based on the culture and social relations, then his personal priorities change.
\end{abstract}

Key words: music therapy, needs of the disabled, transformation.

\section{Introduction}

In any society or its development history the human life is related to potentialities of satisfaction of his needs. The classification of needs, provided in the scientific literature includes physical well-being, development opportunities, relationship with the other people, spiritual improvement. Goodley and Tregaskis (2006) accentuates the need of power and impact on the others, and A. Maslow divides the needs according to the hierarchy, arguing that if the lower, physical needs, ensuring the person's, as a biological being's, existential conditions, are not satisfied, the higher needs will not be relevant for the individual. However, according to Viliūnas (Випиунас, 2006), given the human ability to adapt to changing conditions, due to emotional switching, practically any object can be used as an interim measure to satisfy the needs; therefore the classification of needs is relative. Changing environmental conditions also create the new, more sophisticated hierarchy of needs (Legkauskas, 2004). Disability or illness is one of the changes in living conditions, for which the normal classifications or hierarchies of needs cannot be applied.

Kamal, Currow, Ritchie, Bull (2013) and Tucek (2005) claims that at first the patient or the disabled person meets with the new state, changing emotions, weakening identity. The majority of seriously ill patients or people with hard disorders are characterized by limited communication: significantly impaired intellect, stroke, senile dementia, speech disorder, when the individuals are unable to clearly express their thoughts, cause discomfort in communication. The injuries, amputations, paralysis disrupt the individual's independence, autonomy and privacy status. Being placed in a strange environment (hospital ward, nursing, rehabilitation units and others.) the person becomes dependent on 
the others. Consciously or subconsciously, the feeling of helplessness emerges, that leads to depression and frustration, emotional instability (Lunder, Sauter, Fürst, 2004). Internal conflicts (becoming redundant, loneliness, hopelessness) cause conflicts with the family members, the staff of the health care or social care institutions. Some authors (Pilar Matud, 2004) note the patient's or the disabled person's stress due to loss of sexual identity or changed physical abilities. Thus, we see that the person's illness, injury or disability change the needs at all levels (physical, social, mental). They become limited or unnoticed by the surrounding people, because the disabled person often is unable or reluctant to express them.

There are the health recovery methods in the medicine, but today we more and more tend to complement them with the alternative recuperative sources: physical therapy, occupational therapy, social therapy, art, music therapy, and so on. According to Stige (2004) "it is therapy and social work at the same time, focused on creation of healthy environment, social assistance, network of nursing institutions" (p.102). For four decades the representatives of the music therapy that branched into many related fields of science try to identify the role of music in this situation. Malloch's (2000) theory of communicative musicality, supplementing the infant's and mother's communication statements that from its birth the baby, consciously or on subconscious level, develops its own identity. According to Rean (РeaH ,1999), in the process of adaptation the individual has the opportunity to develop his individual self, going into his inner world (the vertical adaptation vector), accepting or rejecting his disability, diseases, attitude towards himself. Meanwhile, the horizontal vector - social interactions- gives the person the opportunity of togetherness, belonging, listening and desire to be heard. In separate cases (severe disability, illness) horizontal vector as if "contracts" and accessibility of the world becomes dependent on how much of it could be reached by hands, glance or subconscious impulses. Goodley and Tregaskis (2006) point out that in this case the quality of life dimensions and the priorities of needs are more dependent on the perceived gap between the expectations and the actual state. Scientists believe that the needs transform due to the change of conditions- it may be the age, environment, interests and the activity objectives changes. The studies of social psychology of music indicate (Davidson, 2004) that, depending on social interactions and socio-cultural environment, the musical thinking and individual behavior change. This is confirmed by Hargreaves (2002) revealing the diversity of personal identity, its change in the musical and social activities, constantly gaining the new experiences and enriching the own identity. What conditions the disabled people face at home, how they change in the nursing or another health care institution, rehabilitation centre, how the disease changes the approach to values, and thus their needs? This important problem in the scientific literature is examined episodically, in some cases with attention to the physiological needs and support or saving of life. After analysis of psychological nature of the needs, their 
potential transformations in case of disability or illness the problematic question becomes relevant - how the individual needs are revealed during the music therapy sessions, what are the transformations of these needs?

Subject - transformation of the needs of people with disabilities during the music therapy sessions.

Purpose - to examine transformation of the needs of the disabled by applying the music therapy methods.

The questions of research are based on the social interaction theory which explains the personal identity change processes, starting from the human birth, from the beginning of spontaneous communication with the outside world up to the conscious choice of roles in the separate situations (Čirpuvienè, Stošiuviené, 2002; Mead,1967). This refers to the principles of humanistic education, pointing out the search of meaning during the social interactions and the free choice of meaning, meeting the entity and needs of each individual. The study was conducted through analysis of scientific literature, dealing with the needs of people with disabilities, and the case study, where the subject observation data is complemented by the interview method.

\section{Music therapy in the social environment}

Traditionally, in the multi-segment practice of the music therapy (analytical, improvisational, medical, vibro-acoustic, educative, etc.) the socio-cultural environment was ignored, and the developed methods and techniques were applied to any context, i.e. the "pure" methods were created, such as Nordoff Robbins method, the Bonny Method of Guided Imagery, having nothing to do with culture: according to Stige (2004), in the neutral space the client and the music therapist are involved in the process, which is confidential, private, has a clear structure, established techniques, methods, enabling the music therapist to analyze, evaluate, reflect and make generalizations related to the client's status changes. The music therapy does not aim to shape the musical skills. It is, rather, spontaneously arising musical questions and answers, upon which the communication, individual change and development of the person are based.

However, such a provision changes when the music therapy is applied in social work, or the community music therapy. Thinking about the social aspect of problems of the disabled or the patients, it is aimed not to find out more about their disease, diagnosis, but to establish their strongest personal characteristics, socio-cultural context. In other words, standing by the principle of salutogenesis (Antonovsky, 1987), helping the patient to find the inner harmony, trust and meaning. Judging from the social or cultural context, we can point out that the opportunities, provided by the music means to the person, do not fit into the traditional "neutral" music therapy framework: the music, listened to or performed in an open environment, influences the person: the physical gestures help to articulate more clearly (Elefant, 2005), gives the creeps (Holk, 2007), when listening to the music, the people, performing this music, are imagined 
(Aleksiene, 2009; Aldridge, 2005). This is not the above described music therapy, during which the privacy, emotional authenticity are ensured to the client. So, to fully understand the human's state of health, it should be considered in intercultural aspect:

".. If the human life is based on the culture and social relations, then to the human health is connected with this... The human existence is co-existence, and the culture enables and regulates the co-existence. In this way, the music is like a co-existence mode, and the health as the quality of its foundation". (Stige, 2004, p. 96).

The ethnomusicologist Arom (2000) proved that the music of the primitive cultures was the part of social behavior, communication, and the nature of the music itself - to share, to spread - is the basis of cultural identity, precondition for social thinking and behavior. In his opinion, conscious belonging to the national group is the mental health basis, but, according to him, people often realize this only when they find themselves in the difficult life situations. With respect to the needs and possibilities of the disabled, the music therapy can be practiced both individually and in the group, moving the music lessons in a small community. According to Tucek (2005), it is important to understand what the person expects from the music therapy, what his needs are, whether he/ she wants to be alone? Together with the therapist? Group? What human, sociocultural, economic resources are discovered by us? Speaking of the most complex cases of disability or illness O'Callaghan (1989) states:

"When the patients emote into the sounds of music and listen attentively to the words of songs, they no longer feel so alone. They begin to realize that the other people have had to experience the same things they did, in order to sing everything of so realistically.... When people listen to the music of a certain period, they are inundated with the memories and feelings of those days. They feel the friendship and support, provided to them by their family members and friends many years ago ". (P.33).

Suppose the person after severe injury cannot speak. The relationships with his family complicate immediately. He loses his social group - family, colleagues, and has to live and communicate with the strangers, to regain his ability to live. It is a big challenge to his needs, experienced and expressed by the individual in the different ways, so in each case the needs are manifested under the unique, inimitable circumstances.

\section{John's Case}

John had an accident. He lost his job, due to the spinal injury, year after year his health deteriorated: at first he walked with the crutches, later acquired the car for the disabled persons, but his spinal disease progressed, and the man could not walk any more. Hospitals, pensions, narrowing circle of relatives, and John permanently stayed in the nursing department. Due to spinal injury he was unable to walk, so he shrank into himself, did not want to communicate with the 
ward neighbors, medical staff, experienced depression. For the first music therapy sessions it was obvious that he needs the individual music therapy.

Amid the gentle music of Baltic psaltery (kankles) John hid his head under the blanket and gave no indication of a desire to communicate. He lay for a long time without speaking, only a couple of times in a quarter of an hour turned around, looked up quickly the Baltic psaltery, the music therapist, playing it, and then hid under the blanket. It was clear that John was a little concerned about the new and strange musical acts, he has never seen in the ward. This was proved by very brief, but still curious glance at the Baltic psaltery and the man, playing it.

It was obvious that the most important and vital needs of John were limited: the environment - bed, some simple appliances, so that he could easier get up and sit down; narrowed social interactions zone - medical personnel, social workers, rare brother's visits, the ward or department neighbors; deformed identity of the disabled - personality, suppressed by disability burden, completely dependent on the medical staff. Presented situation revealed helplessness of the disabled, dependence on the others.

During the second meeting John looked at the musical instrument and the music therapist a little longer, but then turned away. He did not hide his head under the blanket, turned away and turned back again. He looked longer at the playing instrument.

MT: It is Baltic psaltery... Does this music interfere with you?

$J$. Worthless music. (Says, then smiles and waits for a response).

MT. Worthless? (Laughs). Well, next time I will bring something more joyful. Do you like singing?

$J$. No, I do not. This is not entertainment.

MT. You need more rest, do not you?

J. Yes. (He becomes serious, looks around, as if wishing to affirm something important).

MT. I mean I love music.

$J$. This is your profession.

MT. I use the music to help people. People become a little bit happier. They wait for me to come.

$J$ I I do not. I do not wait for anything, except for death.

This musical session enabled the first social interactions, in the course of which John's identities began to emerge: ability to express his own opinion and assessment ("worthless music") and deep loneliness and emotional emptiness ("I do not wait for anything, except for death").

After four sessions it was noticed that John liked to listen to the folk songs, the easy melody and clear text of which reminded of the life outside the windows of the ward: changing seasons, coming autumn and the maple leaves, already changing the color. The music therapist talks John, who almost never wants to be taken for a walk, about nature, birds, houses. The folk songs are chosen for 
each theme of the meeting. Jonas, who during the first session told that he disliked singing, listened to the performed Lithuanian folk song "The setting of the sun." The song tells the story of the May evening, when the sun goes down, the night covers the earth. And only one bird - the nightingale- does not sleep. It tweets, "as if telling the trees about its troubles".

John looks for a long time, but at the end of the song, raises his hand and says: "I do not know.. but in your eyes I noticed tiredness, probably, you poorly slept at night?". Says, and then laughs, feels embarrassed and turns away.

For the first time, John spoke about the other person, not about his pain and helplessness. The content, the melody of song, the music therapist, sitting next to him and singing, inspired emotional opening, from which John's endeavour to strengthen his identity showed again- the older man's status, allowing him to teach the younger: "this is not entertainment," to notice the other person's tiredness: "your eyes are tired". In the course of social interactions John sought to develop the limits of his inner self and the music therapist enabled him to do this by means of music.

John's moods improved, every week he waited for the sessions, even began to do more physical exercises, because it was discussed that in spring the sessions would take place outdoors, in the garden. He played the drums, sometimes tried to make sounds by the Baltic psaltery. John tried to draw as well. At first he painted what he saw in the immediate surroundings - patterns from the bed quilts, later flowers, which he saw in the ward.

From the interview with the social worker:

"John gave me a lot of drawings. He even wrote down my name on them (smiles). Having gained more confidence, he painted houses, forest, landscapes. The women appeared in his drawings... Look here (turns the drawings), what a nice dress, necklaces, hair. Where does he see them? We do not wear such necklaces... Maybe from memory? Look here - the big speckled birds, houses with the colourful windows and lots of mottled shutters. He now draws everything: events, seasons, flowers..."

Summing up this case, we note that, although the music therapy sessions ended, but the medical staff, social workers left beside the disabled, supported the initiative of John and organized the exhibition of his drawings. At the same time, it proved the theory of Pilar Matud (2004), that the disabled persons or the patients experience stress due to the fact that they cannot express their sexual identity (male, female). From the interview with the social worker it is obvious that the music helped to open the creativity of the disabled and willingness to try his hand at drawing and to express the emotions, gratitude and affection by means of artistic symbols. Knowing that physically he still is and will be confined to the bed or wheelchair, the disabled did not think about the duration of his life. Self-expression and building of emotional connections with people round about became one of the most important needs of him. 


\section{Conclusions}

The needs of each individual cover the most important areas of life: physical well-being, potentiality to develop, relationships with the other people, which also include the opportunities of formation of personal identity in the professional, national, gender aspects and spiritual improvement.

In case of change of the life circumstances, such as disability or illness, the person's needs are limited; therefore the standard hierarchies of needs, provided in scientific literature, cannot be applied.

The music therapy highlights the transformation of the hierarchy of needs: physical strength limit, the concept of life is no longer the basic, but the secondary need. The needs for communication and self-expression become more important than the physical needs. In the course of artistic expression, by the way of the symbolic language of art, the dialogue with the others is established, emoting into phenomena and changes of the nature, the opportunity of strengthening the own identity in the ethnic, gender and age-group aspects and highlighting of the related specifics is discovered.

\section{References}

1. Aldridge, A.(2005). Guidelines in case study design research in music therapy. In: Case study design in music therapy. Ed. D. Aldridge. London and Philadephia: Jessica Kingsley Publishers, p. 235-256.

2. Aleksienè, V. (2009). Lietuviu etnochoreografija autistiškiems vaikams: ugdymo ir terapijos aspektai. Mokslo studija. Vilnius: Ciklonas, X p.

3. Antonovsky, A. (1987) Unraveling the mistery of health. How people manage stress and stay well. San-Francisco: Jossey - Bass,.

4. Arom, S. (2000). Prolegomena to a biomusicology. In N.L. Wallin, B.Merker and S.Brown. The origins of music. London: MIT Press.

5. Čirpuvienè, V., Stošiuvienè, K. (2002). Muzikos poveikis kalbos ugdymui. Iš: Neigaliuju meninis ugdymas: psichologinès reabilitacijos ir socializacijos galimybès. Sud. A. Piličiauskas. Vilnius: Lamuc.

6. Davidson, J. (2004). What can the social psychology of Music offer community music therapy? In Community music therapy. Ed.M.Pavlevic and G.Ansdell. London and Philadephia: Jessica Kingsey Publisher.

7. Elefant, C. (2005). The use of single case designs in testing a specific hypotesis. In: Case study design in music therapy. Ed. D. Aldridge. London and Philadephia: Jessica Kingsley Publishers, p. 145-162.

8. Goodley D., Tregaskis C (2006). Storying Disability and Impairment: Retrospective Accounts of Disabled Family Life // Qualitative Health Research. V.16,p. 630-646..

9. Hargreaves, D., Miell, D., McDonalds, R. (2002). Musical identities. London, Oxford university press.

10. Holck, U. (2007). An ethnographic descriptive approach to video micro analysis. In: Microanalysis in Music therapy. Ed.s T. Wosh and T. Wigram. London and Philadephia: Jessica Kingsey Publishers, p. 29-40.

11. Kamal,A., Currow D.,Ritchie C., Bull J. (2013). Community-Based Palliative Care: The Natural Evolution for Palliative Care Delivery in the U.S. In: Journal of Pain and Symptom Management, Vol. 46,p. 254-264 
12. Kern, P. (2005). The use of single case designs in an interactive play setting. In: Case study design in music therapy. Ed. D. Aldridge. London and Philadephia: Jessica Kingsley Publishers, p. 119-144.

13. Legkauskas, V. (2004). Žmogaus socialinès motyvacijos pagrindai. Sociologija. Mintis ir veiksmas, t.2, p.53-63.

14. Lunder, U., Sauter, S, Fürst, C.F.( 2004). Evidenced - based palliative care: believes and evidence for changing practise. Palliatve medicine, v.18, p.265-266.

15. Malloch, S.N. (1999/2000). Mothers and infants and communicative musicality, Musicae scientiate, p.29-58.

16. McClelland D.(1987). Human motivation. New-York: Cambridge University Press.

17. Mead, G.H, (1967). Mind, self and society: from the standpoint of social behaviorist. Chicago, University of Chicago press.

18. O`Callaghan, C. (1987). Isolation in an Isolated Spot: Music therapy in a palliative care: whats happening now in Australia? In Next step foward. Music therapy with the terminally ill. Proceedings from a symposium for music therapists working in palliative care. New York: Calvary hospital, p.32-33.

19. Pilar Matud, M.(2004). Gender differences in stress and coping styles. Personality and individual differences, V.37, p. 1401-1415.

20. Stige, B. (2004). Community music therapy: Culture, care and wlefare in Ed. M.Pavlevic and G.Ansdell . Community music therapy. Lodon and Philadelphia: Jessica Kingsley Publishers, p.91-113.

21. Tucek, G. (2005). Traditional oriental musictherapy in neurological rehabilitation. In Aldridge D. Music therapy and neurological rehabilitation performing health. London: Jessica Kingsley Publishers, p.211-230.

22. Wosh, T. (2007). Microanalysis in music therapy: introduction and theoretical basis. In: Microanalysis in Music therapy. Eds. T. Wosh and T. Wigram. London and Philadephia: Jessica Kingsley Publishers, p. 13-26.

23. Реан, А. (1999). Психология изучения личности. Санкт Петербург : Изд. Михайлова.

24. Випиунас, В.(2006). Психология развития мотиващии. Санкт Петербург: Реч, 2006.

Prof.dr. Aldona Vilkelienè Lithuanian University of Educational Sciences, Arts Education Department.

E-mail: aldona.vilkeliene@leu.lt 